\title{
Knowledge of Some Issues Related to Preconception Health and Pregnancy among Faculty of Nursing Students, Assiut University
}

\author{
Walaa H. Ibrahim ${ }^{1}$, Shimaa A. Khalaf ${ }^{2, *}$, Walaa H. Abdel-fatah ${ }^{2}$, Shiamaa G. Hassan ${ }^{1}$ \\ ${ }^{1}$ Obstetrics\& Gynecological Nursing, Faculty of Nursing, Assiut University, Egypt \\ ${ }^{2}$ Community Health Nursing, Faculty of Nursing, Assiut University, Egypt \\ *Corresponding author: dr.shaimaaahmed@aun.edu.eg \\ Received April 04, 2019; Revised May 11, 2019; Accepted June 01, 2019
}

\begin{abstract}
Background: Preconception health includes health of woman and man before pregnancy to reduce risks that woman may face during pregnancy and enhance fetal and maternal outcomes. This study aimed to: identify and increase knowledge of the undergraduate nursing students concerning preconception health and pregnancy. Methods: A descriptive cross-sectional study design implemented on 320 nursing students at Faculty of Nursing, Assiut University, tool divided into three parts; part one included students' personal data, part two included eight ended questions directed to students to identify their knowledge regarding preconception health issues and part three designed to evaluate issues related to pregnancy and contained ten ended questions. Results: $38.4 \%$ and $31.6 \%$ of nursing students had good score of knowledge regarding preconception health and pregnancy respectively, there were statistical significant differences between preconception health and students' gender, age, university grade and previous perceived obstetric course ( $\mathrm{P}$-values $=0.013,0.00,0.00$ and 0.00 respectively). Also, there was a relationship between score of students' knowledge regarding pregnancy and their age, university grade and previous perceived obstetric course ( $\mathrm{P}$-values $=0.00,0.00$ and 0.00 respectively). Conclusion: There were relationship between total score of students' knowledge regarding preconception health and pregnancy with student's age, university grade and previous perceived obstetric course. Recommendation: Further research should include all university students in practical versus theoretical faculties to identify how the knowledge and information gaps.
\end{abstract}

Keywords: knowledge, undergraduate students, preconception health, pregnancy

Cite This Article: Walaa H. Ibrahim, Shimaa A. Khalaf, Walaa H. Abdel-fatah, and Shiamaa G. Hassan, "Knowledge of Some Issues Related to Preconception Health and Pregnancy among Faculty of Nursing Students, Assiut University." American Journal of Nursing Research, vol. 7, no. 4 (2019): 574-580. doi: 10.12691/ajnr-7-4-19.

\section{Introduction}

Source of development of any nation is the health and creativity of the youth live in it. Health of new generations affected by health of pregnant women that improved and enhanced through preconception health and counseling. Preconception health means identifying and understanding of current health status of woman and risk factors that may effect on woman or her fetus health in her potential pregnancy. Issues that may involve in preconception health may put fetus in a danger include woman's health condition, medical and obstetrics history, genetic factors, taking of any drugs, exposure to environmental toxins and lifestyle $[1,2,3,4]$.

Common items that involved in preconception health care or counseling: having a healthy body weight, screen for any infectious disease and treat it if present, revision of any medications taken from the woman and follow up controlling of any chronic disease as hypertension and diabetes mellitus. Also maternal nutritional status has an important influence on fetal development and environment surrounded by him. Although preconception health counseling is essential for maternal and fetal health, a wide range of individuals are not aware by component of preconception health counseling $[3,5]$.

Pregnancy outcomes are also linked to the man's lifestyle and health as smoking beside his wife that increase risk low birth weight, so it is important to be included in preconception health counseling. Enhancing youth women and men information, attitudes and behaviors is important issue to promote preconception health and to implement this it is important to reach to youth in universities to improve their awareness about preconception health [6].

Information about preconception health and pregnancy includes many elements to be transmitted to the young men and women such as that more than $50 \%$ of smoking women are unable to get pregnant. Also fertility of men is influenced by cigarettes smoking. Alcohol consumption as cocaine, and excess caffeine intake, so all these issues should be explained and be obvious before conception. Both women and men must to be up-to-date by 
vaccinations to prevent attacking by or transmission of diseases during pregnancy. Also taking $400 \mathrm{mcg}$ daily of folic acid reduce neural tube defects by $75 \%$ that begin 3 months before pregnancy and continue until ending of first trimester of pregnancy $[5,7,8,9,10,11]$.

Data about woman complications which may be faced during pregnancy called high-risk; factors that put woman in high-risk include age more than 35 years, having any medical diseases, obesity, multiple gestation or having problem in previous pregnancy must be provided to the undergraduate to lessen of these complications which may affected on fetal development later on [12].

\subsection{Significance of the Study}

Before achieving educational program about preconception health it is essential to identify extend of information that both women and men have. So, their needs can be identified and focused on the educational program and counseling [12].

Researches that published about preconception health are very limited, also the studies that performed on college students on this object is very limited. So effort should be concentrated on this group of people. It is found that $40 \%$ of studied people not heard about folic acid supplementation before pregnancy to prevent neural tube defects. Most previous researches regarding this point implement their studies on general women and not specify a group of people as university students $[1,6,13]$.

Adolescence is a particularly important point in the Reproductive, Maternal, Newborn and Child health (RMNCH) continuum to promote preconception health. Educating young adolescence about healthy lifestyles not only empowers them as individuals in their own right, but also it can result in healthier maternal and newborn outcomes.

\subsection{Aim of Study}

- To identify knowledge of the undergraduate nursing students about preconception health and pregnancy.

- To improve knowledge of the undergraduate nursing students about preconception health and pregnancy.

\section{Methods}

Research design: Descriptive cross-sectional study design. Setting: This study conducted at Faculty of Nursing, Assiut University, Egypt. Sample size: Was calculating by using EPI - INFO program version 7, at CI 95. The sample was 300 students increased to be 320 to avoid dropout and refusal, this simple was collected from the first to fourth year; 80 students were taken equally from each year by simple random sampling. First and second year did not receive obstetrics and gynecological nursing course, while the third and fourth year had finished the course.

\subsection{Tools of the Study}

A structural self-administered questionnaire designed by the researchers and reviewed by a panel of three experts in obstetrics and gynecological nursing field to evaluate the validity of the tool before starting of data collection. This tool divided into three parts; part one: Personal data of the student as gender, age, university grade, marital status, residence and previously studied course concerning preconception health and pregnancy. Part two: Included eight ended questions to identify students' knowledge regarding preconception health issues. Part three: Designed to evaluate issues related to pregnancy and contained twelve ended questions.

\subsection{Reliability of the Tool}

Reliability calculated by Cronbach's Alpha to test internal consistency it done on 21 items and its result was 0.756 .

\subsection{Scoring System}

A scoring system designed to evaluate students' knowledge contained of 18 questions; eight regarding preconception health and ten for pregnancy issues, a score of one was given for each correct answer and zero was given for don't know or an incorrect answer. Then the total score of each student was summed up and turned into percent for preconception health and pregnancy knowledge separately and then for both of them. This score categorized as the following: poor level of knowledge less than $50 \%$, fair level of knowledge from 50 to $74 \%$ and good level of knowledge equal to or more than $75 \%$.

After filling the questionnaire by the students; the researchers distributed brochure contained information regarding preconception health and pregnancy issues were designed by the researchers to improve the students' knowledge.

\subsection{Ethical Considerations}

An official permission was granted from the Dean of Faculty of Nursing, Assiut University. Each student informed about the purpose of the study and oral consent taken from them before involved in the study. Confidentiality maintained through the research process and each student ensured that all data collected for research purposes only and they had the right to withdraw from the study at any stage.

\subsection{Frame Work}

Data collection carried out in Faculty of Nursing, Assiut University during the academic year 2018/2019 from September 2018 to the beginning of the second semester in March 2019.

\subsection{Procedure}

This study proceeded during two phases; preparation phase: A written acceptance taken from the Dean of Faculty of Nursing, Assiut University and informed agreement from each student before included in the study. The tool of the study prepared and reviewed from a panel of experts in Obstetrics and Gynecological Nursing field. A pilot study carried out on $10 \%$ of sample size that involved in the study sample as no changes were done. Implementation phase: 80 students selected by simple 
random sampling from each academic year; first and second year student did not studied Obstetrics and Gynecological Nursing course; while, third and fourth year studied the course. The researchers divided students to groups each group contained 20 students. The researchers interviewed with students in each group and explained the nature of the study and gained their oral agreement. The researchers put a schedule according to students' free time to interview with each group (20 students) to fill in the questionnaire.

After filling and answering the questions in the questionnaire, all the paper collected and then the researchers distributed brochures to all students participated in the study that contained all information regarding preconception health and pregnancy period and translated into Arabic language. Each interview was taken a time from 45 to 60 minutes. The researchers interviewed with the first, second and fourth year students in the first semester from September to December, 2018 and interviewed with third year in March, 2019 to ensure that they studied an Obstetrics and Gynecological Nursing course.

\subsection{Statistical Analysis}

Data preceded through process of entry; cleaning and recoding were done using the Statistical Package for Social Science (SPSS Inc., Chicago, IL, USA) version 20. Statistical analysis on data was done using:

Descriptive statistics: frequencies and percentage for qualitative variables.

Pearson's X2 was used to test the difference between frequencies of qualitative data.

Statistical significance was considered when $\mathrm{p}<0.05$.

\section{Results}

Table 1: Indicates that $75.9 \%$ of the students were aged 19 years and more, $71.9 \%$ of them were female, the vast majority $(96.6 \%)$ were single and more than half $(54.7 \%)$ were from rural area.

Table 2: Comprises questions regarding preconception health, it revealed that the percent of correct answer were $52.5 \%, 33.1 \%, 55.3 \%, 61.9 \%, 88.8 \%$ respectively in referral to knowledge about regular sexual intercourse, taking folic acid supplementation, supplementation effective in prevention of neural defect, timing of ovulation and blood test done before pregnancy.

Table 3: Represents that the correct answer of students regarding pregnancy were $60.3 \%, 66.6 \%, 61.6 \%, 61.3 \%$, $90.9 \%$ respectively in answering questions about correct time of taken folic acid, disease more likely cause preeclampsia, disease cause over weight baby, full term duration of pregnancy and presence of pregnancy stages.

Figure 1: Indicates that $38.4 \%$ of the students had good score of knowledge about preconception health while, $38.1 \%$ and $23.4 \%$ of them had faire and poor score of knowledge respectively.

Figure 2: Declares that $39.7 \%$ of the students had poor level of knowledge regarding pregnancy while $31.6 \%$ and $28.8 \%$ had good and faire level of knowledge respectively.
Table 1. Personal data of the undergraduate nursing students

\begin{tabular}{|l|c|c|}
\hline Items & No. (320) & \% \\
\hline Age (years): & & \\
\hline Less than 19 years & 77 & 24.1 \\
\hline 19 years and more & 243 & 75.9 \\
\hline Student's gender: & & \\
\hline Male & 90 & 28.1 \\
\hline Female & 230 & 71.9 \\
\hline Marital status: & & \\
\hline Single & 309 & 96.6 \\
\hline Married & 11 & 3.4 \\
\hline Residence: & 145 & 45.3 \\
\hline Urban & 175 & 54.7 \\
\hline Rural & & \\
\hline Received previous obstetric course: & 160 & 50 \\
\hline Yes & 160 & 50 \\
\hline No & & \\
\hline
\end{tabular}

Table 2. Distribution of knowledge about preconception health among undergraduate nursing students

\begin{tabular}{|c|c|c|}
\hline Items & No. (320) & $\%$ \\
\hline \multicolumn{3}{|c|}{$\begin{array}{l}\text { 1) Regular sexual intercourse every two or } \\
\text { three days around time of ovulation }\end{array}$} \\
\hline True & 168 & 52.5 \\
\hline False & 22 & 6.9 \\
\hline Don't know & 130 & 40.6 \\
\hline \multicolumn{3}{|c|}{$\begin{array}{l}\text { 2) Taking a supplementation with folic acid } \\
\text { before pregnancy }\end{array}$} \\
\hline From 1 to 3 days & 18 & 5.6 \\
\hline From 1 to 3 weeks & 21 & 6.6 \\
\hline From 1 to 3 months & 106 & 33.1 \\
\hline Don't know & 175 & 54.7 \\
\hline \multicolumn{3}{|c|}{$\begin{array}{l}\text { 3) Effective in prevention of neural tube } \\
\text { defect as spina bifida for the newborn baby }\end{array}$} \\
\hline Folic acid & 177 & 55.3 \\
\hline Calcium & 57 & 17.8 \\
\hline Iron & 15 & 4.7 \\
\hline Don't know & 71 & 22.2 \\
\hline \multicolumn{3}{|l|}{ 4) Timing of ovulation } \\
\hline 1-10 day of the menstrual cycle & 46 & 14.4 \\
\hline 11-21 day of the menstrual cycle & 198 & 61.9 \\
\hline $22-28$ day of the menstrual cycle & 25 & 7.8 \\
\hline Don't know & 51 & 15.9 \\
\hline \multicolumn{3}{|c|}{$\begin{array}{l}\text { 5) Women before pregnancy need to perform } \\
\text { blood test to identify }\end{array}$} \\
\hline Blood grouping & 4 & 1.3 \\
\hline Hemoglobin & 9 & 2.8 \\
\hline RH & 284 & 88.8 \\
\hline Don't know & 23 & 7.2 \\
\hline \multicolumn{3}{|c|}{$\begin{array}{l}\text { 6) Using illicit drugs if a pregnancy is not } \\
\text { desired }\end{array}$} \\
\hline True & 148 & 46.3 \\
\hline False & 125 & 39.1 \\
\hline Don't know & 47 & 14.7 \\
\hline \multicolumn{3}{|c|}{$\begin{array}{l}\text { 7) Avoid cleaning cat litter trays to avoid } \\
\text { exposure to }\end{array}$} \\
\hline Rubella & 22 & 6.9 \\
\hline Toxemia & 21 & 6.6 \\
\hline Toxoplasmosis & 217 & 67.8 \\
\hline Don't know & 60 & 18.8 \\
\hline \multicolumn{3}{|c|}{$\begin{array}{l}\text { 8) Pre-conception counseling is also relevant } \\
\text { to men }\end{array}$} \\
\hline True & 271 & 84.7 \\
\hline False & 20 & 6.3 \\
\hline Don't know & 29 & 9.1 \\
\hline
\end{tabular}


Table 3. Distribution of pregnancy knowledge among undergraduate nursing students

\begin{tabular}{|c|c|c|}
\hline Items & No.(320) & $\%$ \\
\hline \multicolumn{3}{|c|}{ 1) Correct time in which women take folic acid } \\
\hline First three months of pregnancy & 193 & 60.3 \\
\hline Second three months of pregnancy & 24 & 7.5 \\
\hline Third three months of pregnancy & 31 & 9.7 \\
\hline Don’t know & 72 & 22.5 \\
\hline \multicolumn{3}{|c|}{ 2) Disease is more likely cause preeclampsia } \\
\hline Diabetes mellitus & 24 & 7.5 \\
\hline Anemia & 23 & 7.2 \\
\hline Hypertension & 213 & 66.6 \\
\hline Don't know & 60 & 18.8 \\
\hline \multicolumn{3}{|c|}{ 3) Over weight baby is resulting from } \\
\hline Diabetes mellitus & 197 & 61.6 \\
\hline Hypertensions & 11 & 3.4 \\
\hline Heart disease & 19 & 5.9 \\
\hline Don't know & 93 & 29.1 \\
\hline \multicolumn{3}{|l|}{ 4) Full term duration of pregnancy } \\
\hline 35 week & 72 & 22.5 \\
\hline 40 week & 196 & 61.3 \\
\hline 45 week & 27 & 8.4 \\
\hline Don't know & 25 & 7.8 \\
\hline \multicolumn{3}{|c|}{ 5) Expected weight gain during pregnancy } \\
\hline $3-5 \mathrm{~kg}$ & 53 & 16.6 \\
\hline $5-10 \mathrm{~kg}$ & 121 & 37.8 \\
\hline $11-16 \mathrm{~kg}$ & 82 & 25.6 \\
\hline Don't know & 64 & 20.0 \\
\hline \multicolumn{3}{|c|}{$\begin{array}{l}\text { 6) Women with low risk pregnancy needed to be } \\
\text { followed up as a visit more likely }\end{array}$} \\
\hline In the first month & 128 & 40.0 \\
\hline In the second trimester & 42 & 13.1 \\
\hline In the last month & 90 & 28.1 \\
\hline Don't know & 60 & 18.8 \\
\hline \multicolumn{3}{|l|}{ 7) There are stages of pregnancy } \\
\hline True & 291 & 90.9 \\
\hline False & 10 & 3.1 \\
\hline Don't know & 19 & 5.9 \\
\hline \multicolumn{3}{|c|}{$\begin{array}{l}\text { 8) The first perceptible fetal movement is take } \\
\text { place by .........weeks }\end{array}$} \\
\hline $10-12$ & 33 & 10.3 \\
\hline $12-15$ & 96 & 30.0 \\
\hline $16-18$ & 128 & 40.0 \\
\hline Don't know & 63 & 19.7 \\
\hline \multicolumn{3}{|c|}{$\begin{array}{l}\text { 9) Placenta is completed formed and ready to } \\
\text { perform their functions }\end{array}$} \\
\hline By 10 weeks & 42 & 13.1 \\
\hline By 12 weeks & 127 & 39.7 \\
\hline By 16 weeks & 75 & 23.4 \\
\hline Don't know & 76 & 23.8 \\
\hline \multicolumn{3}{|c|}{$\begin{array}{l}\text { 10) Distinguish the sex of the fetus through using } \\
\text { ultrasonography }\end{array}$} \\
\hline Week $5-8$ of gestation & 32 & 10.0 \\
\hline Week 9-12 of gestation & 79 & 24.7 \\
\hline Week $16-18$ of gestation & 149 & 46.6 \\
\hline Don't know & 60 & 18.8 \\
\hline
\end{tabular}

Table 4: Shows that there were statistically significant differences between level of knowledge regarding preconception health and student's gender, age, university grade and previous perceived obstetric course ( $\mathrm{P}$ values $=0.013,0.00,0.00$ and 0.00 respectively).

Table 5: Clears that there were relationship between score of students' knowledge regarding pregnancy and their age, university grade and previous perceived obstetric course ( $P$ values $=0.00,0.00$ and 0.00 respectively).
Table 6: Clarify that there were statistically significant differences between total score of students' knowledge regarding preconception health and pregnancy with their age, university grade and previous perceived obstetric course ( $P$ values $=0.00,0.00$ and 0.00 respectively).

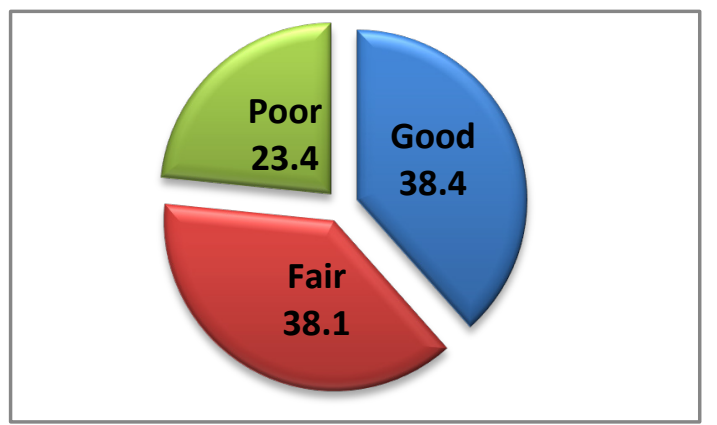

Figure 1. Total score of preconception health knowledge among undergraduate nursing students

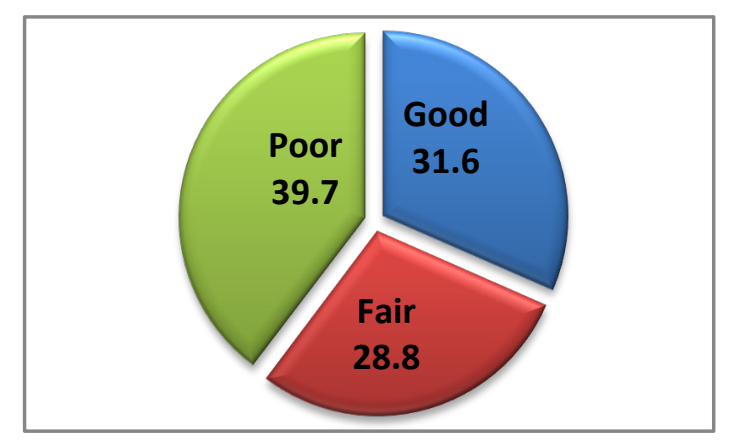

Figure 2. Total score of pregnancy knowledge among undergraduate nursing students

Table 4. Relationship between personal data and total score of students' knowledge regarding preconception health

\begin{tabular}{|c|c|c|c|c|c|}
\hline \multicolumn{2}{|c|}{ Personal data } & \multicolumn{3}{|c|}{$\begin{array}{c}\text { Preconception health } \\
\text { score }(n=320)\end{array}$} & \multirow[t]{2}{*}{ P-Value } \\
\hline & & Good & Fair & Poor & \\
\hline \multirow{4}{*}{$\begin{array}{l}\text { Student's } \\
\text { gender }\end{array}$} & \multirow{2}{*}{ Male } & 35 & 25 & 30 & \multirow{4}{*}{$0.013 *$} \\
\hline & & $38.9 \%$ & $27.8 \%$ & $33.3 \%$ & \\
\hline & \multirow{2}{*}{ Female } & 88 & 97 & 45 & \\
\hline & & $38.3 \%$ & $42.2 \%$ & $19.6 \%$ & \\
\hline \multirow{4}{*}{$\begin{array}{l}\text { Student's } \\
\text { age }\end{array}$} & \multirow{2}{*}{$\begin{array}{l}\text { Less than } 19 \\
\text { years }\end{array}$} & 9 & 30 & 38 & \multirow{4}{*}{$0.000 *$} \\
\hline & & $11.7 \%$ & $39.0 \%$ & $49.4 \%$ & \\
\hline & \multirow{2}{*}{$\begin{array}{l}19 \text { years and } \\
\text { more }\end{array}$} & 114 & 92 & 37 & \\
\hline & & $46.9 \%$ & $37.9 \%$ & $15.2 \%$ & \\
\hline \multirow{4}{*}{ Residence } & \multirow{2}{*}{ Urban area } & 54 & 51 & 40 & \multirow{4}{*}{0.266} \\
\hline & & $37.2 \%$ & $35.2 \%$ & $27.6 \%$ & \\
\hline & \multirow{2}{*}{ Rural area } & 69 & 71 & 35 & \\
\hline & & $39.4 \%$ & $40.6 \%$ & $20.0 \%$ & \\
\hline \multirow{8}{*}{$\begin{array}{l}\text { University } \\
\text { grade }\end{array}$} & \multirow{2}{*}{ First year } & 12 & 29 & 39 & \multirow{8}{*}{$0.000 *$} \\
\hline & & $15.0 \%$ & $36.3 \%$ & $48.8 \%$ & \\
\hline & \multirow{2}{*}{ Second year } & 3 & 61 & 16 & \\
\hline & & $3.8 \%$ & $76.3 \%$ & $20.0 \%$ & \\
\hline & \multirow{2}{*}{ Third year } & 50 & 20 & 10 & \\
\hline & & $62.5 \%$ & $25.0 \%$ & $12.5 \%$ & \\
\hline & \multirow{2}{*}{ Fourth year } & 58 & 12 & 10 & \\
\hline & & $72.5 \%$ & $15.0 \%$ & $12.5 \%$ & \\
\hline \multirow{4}{*}{$\begin{array}{c}\text { Marital } \\
\text { status }\end{array}$} & \multirow{2}{*}{ Single } & 120 & 115 & 74 & \multirow{4}{*}{0.191} \\
\hline & & $38.8 \%$ & $37.2 \%$ & $23.9 \%$ & \\
\hline & \multirow{2}{*}{ Married } & 3 & 7 & 1 & \\
\hline & & $27.3 \%$ & $63.6 \%$ & $9.1 \%$ & \\
\hline \multirow{4}{*}{$\begin{array}{c}\text { Received } \\
\text { previous } \\
\text { obstetric } \\
\text { course }\end{array}$} & \multirow{2}{*}{ Yes } & 111 & 40 & 29 & \multirow{4}{*}{$0.000 *$} \\
\hline & & $61.7 \%$ & $22.2 \%$ & $16.1 \%$ & \\
\hline & \multirow{2}{*}{ No } & 12 & 82 & 46 & \\
\hline & & $8.6 \%$ & $58.6 \%$ & $32.9 \%$ & \\
\hline
\end{tabular}

Chi square test, $\mathrm{P}$ value $=<0.05, *$ statistically significance difference 
Table 5. Relationship between personal data and total score of students' knowledge regarding pregnancy

\begin{tabular}{|c|c|c|c|c|c|}
\hline \multirow{2}{*}{\multicolumn{2}{|c|}{ Personal data }} & \multicolumn{3}{|c|}{ Pregnancy score $(n=320)$} & \multirow{2}{*}{ P -Value } \\
\hline & & Good & Fair & Poor & \\
\hline \multirow{4}{*}{$\begin{array}{l}\text { Student's } \\
\text { gender }\end{array}$} & \multirow{2}{*}{ Male } & 21 & 33 & 36 & \multirow{4}{*}{0.07} \\
\hline & & $23.3 \%$ & $36.7 \%$ & $40.0 \%$ & \\
\hline & \multirow{2}{*}{ Female } & 80 & 59 & 91 & \\
\hline & & $34.8 \%$ & $25.7 \%$ & $39.6 \%$ & \\
\hline \multirow{4}{*}{$\begin{array}{l}\text { Student's } \\
\text { age }\end{array}$} & Less than & 2 & 14 & 61 & \multirow{4}{*}{$0.00^{*}$} \\
\hline & 19 years & $2.6 \%$ & $18.2 \%$ & $79.2 \%$ & \\
\hline & \multirow{2}{*}{$\begin{array}{l}19 \text { years } \\
\text { and more }\end{array}$} & 99 & 78 & 66 & \\
\hline & & $40.7 \%$ & $32.1 \%$ & $27.2 \%$ & \\
\hline \multirow{4}{*}{ Residence } & \multirow{2}{*}{$\begin{array}{c}\text { Urban } \\
\text { area }\end{array}$} & 41 & 37 & 67 & \multirow{4}{*}{0.09} \\
\hline & & $28.3 \%$ & $25.5 \%$ & $46.2 \%$ & \\
\hline & \multirow{2}{*}{$\begin{array}{c}\text { Rural } \\
\text { area }\end{array}$} & 60 & 55 & 60 & \\
\hline & & $34.3 \%$ & $31.4 \%$ & $34.3 \%$ & \\
\hline \multirow{8}{*}{$\begin{array}{c}\text { University } \\
\text { grade }\end{array}$} & \multirow{2}{*}{ First year } & 2 & 16 & 62 & \multirow{8}{*}{$0.00^{*}$} \\
\hline & & $2.5 \%$ & $20.0 \%$ & $77.5 \%$ & \\
\hline & \multirow{2}{*}{$\begin{array}{c}\text { Second } \\
\text { year }\end{array}$} & 6 & 32 & 42 & \\
\hline & & $7.5 \%$ & $40.0 \%$ & $52.5 \%$ & \\
\hline & \multirow{2}{*}{$\begin{array}{l}\text { Third } \\
\text { year }\end{array}$} & 39 & 25 & 16 & \\
\hline & & $48.8 \%$ & $31.3 \%$ & $20.0 \%$ & \\
\hline & \multirow{2}{*}{$\begin{array}{c}\text { Fourth } \\
\text { year }\end{array}$} & 54 & 19 & 7 & \\
\hline & & $67.5 \%$ & $23.8 \%$ & $8.8 \%$ & \\
\hline \multirow{4}{*}{$\begin{array}{c}\text { Marital } \\
\text { status }\end{array}$} & \multirow{2}{*}{ Single } & 98 & 89 & 122 & \multirow{4}{*}{0.92} \\
\hline & & $31.7 \%$ & $28.8 \%$ & $39.5 \%$ & \\
\hline & \multirow{2}{*}{ Married } & 3 & 3 & 5 & \\
\hline & & $27.3 \%$ & $27.3 \%$ & $45.5 \%$ & \\
\hline \multirow{4}{*}{$\begin{array}{l}\text { Received } \\
\text { previous } \\
\text { obstetric } \\
\text { course }\end{array}$} & \multirow{2}{*}{ Yes } & 94 & 50 & 36 & \multirow{4}{*}{$0.00^{*}$} \\
\hline & & $52.2 \%$ & $27.8 \%$ & $20.0 \%$ & \\
\hline & \multirow{2}{*}{ No } & 7 & 42 & 91 & \\
\hline & & $5.0 \%$ & $30.0 \%$ & $65.0 \%$ & \\
\hline
\end{tabular}

Chi square test, $\mathrm{P}$ value $=<0.05$, *Statistically significance difference.

Table 6. Relationship between personal data and total score of students' knowledge regarding preconception health and pregnancy

\begin{tabular}{|c|c|c|c|c|c|}
\hline \multirow{2}{*}{\multicolumn{2}{|c|}{ Personal data }} & \multicolumn{3}{|c|}{ Total score $(\mathrm{n}=\mathbf{3 2 0})$} & \multirow{2}{*}{ P - Value } \\
\hline & & \multirow{2}{*}{$\begin{array}{c}\text { Good } \\
22 \\
\end{array}$} & \multirow{2}{*}{$\begin{array}{c}\text { Fair } \\
50 \\
\end{array}$} & \multirow{2}{*}{$\begin{array}{c}\text { Poor } \\
18 \\
\end{array}$} & \\
\hline \multirow{4}{*}{$\begin{array}{l}\text { Student's } \\
\text { gender }\end{array}$} & \multirow{2}{*}{ Male } & & & & \multirow{4}{*}{0.36} \\
\hline & & $24.4 \%$ & $55.6 \%$ & $20.0 \%$ & \\
\hline & \multirow{2}{*}{ Female } & 75 & 115 & 40 & \\
\hline & & $32.6 \%$ & $50.0 \%$ & $17.4 \%$ & \\
\hline \multirow{4}{*}{$\begin{array}{l}\text { Student's } \\
\text { age }\end{array}$} & \multirow{2}{*}{$\begin{array}{c}\text { Less than } 19 \\
\text { year }\end{array}$} & 1 & 37 & 39 & \multirow{4}{*}{$0.00^{*}$} \\
\hline & & $1.3 \%$ & $48.1 \%$ & $50.6 \%$ & \\
\hline & \multirow{2}{*}{$\begin{array}{l}19 \text { years and } \\
\text { more }\end{array}$} & 96 & 128 & 19 & \\
\hline & & $39.5 \%$ & $52.7 \%$ & $7.8 \%$ & \\
\hline \multirow{4}{*}{ Residence } & \multirow{2}{*}{ Urban area } & 41 & 71 & 33 & \multirow{4}{*}{0.15} \\
\hline & & $28.3 \%$ & $49.0 \%$ & $22.8 \%$ & \\
\hline & \multirow{2}{*}{ Rural area } & 56 & 94 & 25 & \\
\hline & & $32.0 \%$ & $53.7 \%$ & $14.3 \%$ & \\
\hline \multirow{8}{*}{$\begin{array}{l}\text { University } \\
\text { grade }\end{array}$} & \multirow{2}{*}{ First year } & 2 & 38 & 40 & \multirow{8}{*}{$0.00^{*}$} \\
\hline & & $2.5 \%$ & $47.5 \%$ & $50.0 \%$ & \\
\hline & \multirow{2}{*}{ Second year } & 2 & 67 & 11 & \\
\hline & & $2.5 \%$ & $83.8 \%$ & $13.8 \%$ & \\
\hline & \multirow{2}{*}{ Third year } & 36 & 40 & 4 & \\
\hline & & $45.0 \%$ & $50.0 \%$ & $5.0 \%$ & \\
\hline & \multirow{2}{*}{ Fourth year } & 57 & 20 & 3 & \\
\hline & & $71.3 \%$ & $25.0 \%$ & $3.8 \%$ & \\
\hline \multirow{4}{*}{$\begin{array}{l}\text { Marital } \\
\text { status }\end{array}$} & \multirow{2}{*}{ Single } & 94 & 159 & 56 & \multirow{4}{*}{0.97} \\
\hline & & $30.4 \%$ & $51.5 \%$ & $18.1 \%$ & \\
\hline & \multirow{2}{*}{ Married } & 3 & 6 & 2 & \\
\hline & & $27.3 \%$ & $54.5 \%$ & $18.2 \%$ & \\
\hline \multirow{4}{*}{$\begin{array}{c}\text { Received } \\
\text { previous } \\
\text { obstetric } \\
\text { course }\end{array}$} & \multirow{2}{*}{ Yes } & 94 & 72 & 14 & \multirow{4}{*}{$0.00^{*}$} \\
\hline & & $52.2 \%$ & $40.0 \%$ & $7.8 \%$ & \\
\hline & No & 3 & 93 & 44 & \\
\hline & No & $2.1 \%$ & $66.4 \%$ & $31.4 \%$ & \\
\hline
\end{tabular}

Chi square test, $\mathrm{P}$ value $=<0.05$, *statistically significance difference.

\section{Discussion}

Preconception health care means any intervention that given before pregnancy and offered to both gender of childbearing age, regardless of the desire to get pregnancy, to improve health outcomes for women, and newborns. It is a complementary part of antenatal care because this care program potentially assists women to reduce risk, promote healthy lifestyle and improve readiness for pregnancy [14].

The present study aimed to assess knowledge of the undergraduate students at Faculty of Nursing, Assiut University regarding some issues related to preconception health and pregnancy.

Regarding age of the participants; the results of this study cleared that three fifths of the students were aged 19 years and more. This finding was in accordance with [14] who performed a study to assess knowledge and practice regarding preconception health care among antenatal mothers in Nepal and found that half of the participants were in the age group from 21-25 years. Also, it is agreed with [15] who conducted a study to assess knowledge on preconception health care among reproductive age women and observed that about half of the respondents were from age group 21-25 years.

While in a study carried out by [6] entitled improving awareness of preconception health among adolescents: experience of a school-based intervention in Lebanon and reported that three-quarters of the participants were aged between 14 and 18 years. This difference came from intervention of the last study on adolescents.

In the present study nearly three-fifths of students were female, this observation in the same line with [6] who reported that the majority of students were female. Also [16] who apply an online study to identify undergraduates' knowledge and attitudes of preconception health care found that $77 \%$ of participant was female.

Regarding marital status of students only $3.4 \%$ of them were married, this data disagreed with [6] who mentioned that more than one-fifth of the students were married. And nearly half $(47.3 \%)$ of participants were married in [17], who performed their study in Hawassa, Ethiopia to assess knowledge of preconception health care among healthcare providers working in public health institutions. Variation between this study and [17] occurred related to difference in working status as the first participants were students and the second participant were employed that give them a chance to take a responsibility of marriage.

More than half of the students were from rural area in the present study, but [18] who done their study on reproductive-age United States women to evaluate their knowledge, attitudes, and practices regarding conception and fertility, reported that one quarter were from rural area and [19] who performed their study in Ruiru sub-country, Kiambu country, Kenya to assess the knowledge on pre conception care among women of reproductive age and found that $28.4 \%$ of the participant were from rural area. Dissimilarity between them related to difference in study's location.

In referral to students' knowledge about folic acid; the current study revealed that one third of the student known that it must be taken before pregnancy from 1-3 months; this observation was in contrast with [14] who reported that only $6 \%$ known the correct answer. 
According to the total score of preconception health knowledge, it was found that more than one third of undergraduate students in the current study had good score of knowledge. That was in accordance with [19] who found that more than one third of the participants had adequate knowledge. This result disagreed with [14] who recorded that more than half of the respondents had inadequate level of knowledge, as it applied on antenatal mothers. [20] who carried out a study to identify knowledge and attitude of students in Menoufia University, Shebin Elkom city toward premarital care and showed that nearly half of the practical undergraduate students had good score of knowledge.

In accordance to the relationship between students' personal data and their score of knowledge about preconception health; the current study estimated that there were statistically significant differences between gender, age, university grade and perceived previous obstetric course $(\mathrm{P}$ values $=0.013,0.000,0.000$ and 0.000 respectively). Where there weren't any statistically significance difference in relation to residence and marital status ( $\mathrm{P}$ values $=0.266$ and 0.191 respectively). [19] showed that knowledge level of preconception health was significantly associated is age $(\chi 2=10.976, \mathrm{P}<0.05, \mathrm{df}=1)$. While, [15] found that no relationship between age and educational status and level of knowledge about preconception health care p-value 0.926 and 0.264 respectively, as it applied on reproductive age women.

The present study declared that there were statistically significance differences between students age, university grade and previous received obstetric course and their score of knowledge regarding pregnancy $(P$ values $=0.00$, 0.00 and 0.00 respectively); while there weren't any relationship in referral to students gender, residence and marital status ( $\mathrm{P}$ value $=0.07,0.09$ and 0.92 respectively).

The findings of the current study clarified that there were relationship between total score of knowledge regarding preconception health and pregnancy with students' age, university grade and previous perceived obstetric course ( $\mathrm{P}$ value $=0.00,0.00$ and 0.00 respectively); in contrast there weren't any relationship between gender, residence and marital status ( $\mathrm{P}$ value $=0.36,0.15$ and 0.97 respectively).

\section{Conclusion}

- This study highlights that around one third of nursing students were had good score of knowledge regarding preconception health and pregnancy. It was concluded that there were relation between total score of students' knowledge regarding preconception health and pregnancy with student's age, university grade and previous perceived obstetric course. Preconception health is not a topic specific to women, and research should including both genders male and female.

\section{Recommendations}

- Development of health education programs to increase students' knowledge of preconception health and pregnancy.
- Strengthening the University with an office responsible for the provision of health education for students about preconception health and pregnancy.

- Further research should include all university student in practical versus theoretical faculties to identify how the knowledge and information gaps.

\section{Acknowledgments}

- The researchers grateful to Faculty of Nursing, Assuit University for its support to accomplish this study.

- Many thanks to all students for their participation in the study, without whom this study would be impossible.

\section{Funding Sources}

No.

\section{Conflict of Interest}

None.

\section{References}

[1] El Gelany S. and Moussa O., (2012). Reproductive health awareness among educated young women in Egypt. International Journal of Gynecology and Obstetrics, 120 (2013) 23-26.

[2] Delgado C., (2013). Pregnancy 101: A Call for Reproductive and Prenatal Health Education in College, Springer Science Business Media, LLC 2012

[3] Stephenson J., Patel D., Barrett G., Howden B., Copas A., Ojukwu O., Pandya P., Shawe J., (2014). How Do Women Prepare for Pregnancy? Preconception health, Experiences of Women Attending Antenatal Services and Views of Health Professionals, PLOS ONE, www.plosone.org, Vol. 9, Issue 7, page 1-10.

[4] Floyd R., Johnson K., Owens J., Verbiest S., Moore C., and Boyle Boyle C., (2015). A National Action Plan for Promoting Preconception health Health and Health Care in the United States (2012-2014), J Women Health (Larchmt). Author manuscript; 22(10): 797-802.

[5] Farahi N. and Zolotor A., (2013). Recommendations for Preconception health Counseling and Care, www.aafp.org/afp American Family Physician, Vol. 88, No. 8, 499-506.

[6] Charafeddine L., El Rafei R., Azizi S., Sinno D., Alamiddine K., Howson C., Walani S., Ammar W., Nassarand A. and Yunis K., (2014). Improving awareness of preconception health among adolescents: experience of a school-based intervention in Lebanon, BMC Public Health, pp 14:774.

[7] Robinson D. and Klein S., (2012). Pregnancy and pregnancyassociated hormones alter immune responses and disease pathogenesis. Horm. Behav. 62 (3): 263-271.

[8] Zhang Z., Zhu H., Li L., Yu Y., Zhang H. and Liu R., (2013). Decline of semen quality and increase of leukocytes with cigarette smoking in infertile men. Iran J. Reprod. Med. 11 (7), pp. 589-596.

[9] Mendelsohn C., Gould G. and Oncken C., (2014). Management of smoking in pregnant women. Aust. Fam. Physician 43 (1-2), 46-51.

[10] Horne A., Brown J., Nio-Kobayashi J., Abidin H., Adin Z., Boswell L. and Duncan W., (2014). The association between smoking and ectopic pregnancy: why nicotine is bad for your fallopian tube. PLoS One 9 (2): 1-7.

[11] Toivonen K., Oinonen K. and Duchene K., (2016). Preconception health behaviors: A scoping review, Preventive Medicine 96 (2017) $1-15$. 
[12] Delgado C., (2008). Undergraduate Student Awareness of Issues Related to Preconception health Health and Pregnancy, Maternal Child Health J (2008) 12: 774-782.

[13] Paulsen A., (2017). Preconception Health Knowledge among Undergraduate Women, A Thesis Submitted in Partial Fulfillment of the Requirements for the Degree of Master of Science, Minnesota State University.

[14] Nepali G. and Sapkota S., (2017). Knowledge and practice regarding preconception health care among antenatal mothers, International Journal of Perceptions in Public Health; 1(4): 224-227.

[15] Gautam P. and Dhakal R., (2016). Knowledge on Preconception health Care among Reproductive age Women. Saudi Journal of Medical and Pharmaceutical Sciences; 2(1); 1-6.

[16] Crusenberry J., (2016). An online study of undergraduates' knowledge, awareness, and attitudes of preconception health care, University of Tennessee, Knoxville Trace: Tennessee Research and Creative Exchange, Masters Thesis.
[17] Kassa A., Human S. and Gemeda H., (2018). Knowledge of preconception health care among healthcare providers working in public health institutions in Hawassa, Ethiopia, PLoS ONE 13 (10) $\mathrm{e} 0204415$.

[18] Lisbet S. Lundsberg M., Pal L., Gariepy A., Chu M. and Illuzzi J., (2014). Knowledge, attitudes, and practices regarding conception and fertility: a population-based survey among reproductive-age United States women, Fertility and Sterility ${ }^{\circledR}$ Vol. 101, No. 3, American Society for Reproductive Medicine, Published by Elsevier Inc.

[19] Joyce C., Keraka M. and Njagi J., (2018). Assessment of the knowledge on pre conception care among women of reproductive age in Ruiru sub-country, Kiambu country, Kenya, Global Journal of Health Science, Vol.3, Issue 1, No.5, p.p 82-100.

[20] Farahata T., Shaheen H., Mohamed H. and Mohaseb M., (2014). Knowledge and attitude of students in Menoufia University, Shebin Elkom city toward premarital care in 2012, Menoufia Medical Journal, 27: 347-352. 